\title{
Medicines Value Chain Management Level in Cuban Health System
}

Nivel de gestión de la red de valor de medicamentos en el sistema de salud cubano

Received: February 28, 2019 | Accepted: October 23, 2019 | Published: February 24, 2020

\section{Teresita López-Joy}

Universidad Tecnológica de La Habana, Cuba.

ORCID: https://orcid.org/0000-0003-4579-9197

\section{Ana Julia Acevedo-Urquiaga ${ }^{a}$}

Fundación Universitaria San Mateo, Colombia.

Centro Europeo-Latinoamericano de Logística y Proyectos Ecológicos

ORCID: https://orcid.org/0000-0001-7867-1590

\section{Martha Inés Gómez-Acosta}

Universidad Tecnológica de La Habana, Cuba.

ORCID: https://orcid.org/0000-0003-0346-5340

\section{Adis Nubia Neira-Mugercia}

Universidad Tecnológica de La Habana, Cuba.

ORCID: https://orcid.org/0000-0002-9335-4216

\section{José Antonio Acevedo-Suárez}

Universidad Tecnológica de La Habana, Cuba.

ORCID: https://orcid.org/0000-0001-8862-6718

\section{Claudia Peña-García}

Universidad Tecnológica de La Habana, Cuba.

ORCID: https://orcid.org/0000-0002-2839-8263

${ }^{*}$ Review article.

aCorresponding author. Email: anajuliaa@gmail.com

DOI: https://doi.org/10.11144/Javeriana.iyu24.mvem

\section{How to cite this article:}

T. López-Joy, M. I. Gómez-Acosta, A. N. Neira-Mugercia, J. A. Acevedo-Suárez, C. Peña-García, and A. J. AcevedoUrquiaga, "Medicines value chain management level in Cuban health system," Ing. Univ., vol. 24, 2020. https://doi.org/10.11144/Javeriana.iyu24.mvcm 


\section{Abstract}

The value networks management in the pharmaceutical sector is fundamental to guide the work of health entities to the demands of patients. The Cuban health system is characterized by the full and free access of its citizens to these services. The medicines supply chain is of vital importance to complete health services, and in Cuba a specialized logistics operator manages it. This focuses on achieving the medicines availability according to the patients' demands. This study presents the medicine supply chain and the evolution of its management level since 2015. The qualitative evaluation of its performance is carried out using the Value Network Reference Model as a methodological tool. The result shows that in 2018 the medicines chain reach a medium performance level and that, based on this diagnosis, the development projects are elaborated according to the needs identified. The Cuban medicines supply chain is a reference of the logistic support that sustains this health system and for other chains in Cuba, when it shows management levels above the national average of three points.

Keywords: value chain; logistic; medicines supply chain; Value Chain Reference Model

\section{Resumen}

La gestión de redes de valor en la rama farmacéutica constituye una herramienta fundamental para orientar el trabajo de las entidades de salud hacia las demandas de los pacientes. El sistema de salud cubano se caracteriza por el acceso pleno y gratuito de sus ciudadanos a dichos servicios. La cadena de valor de medicamentos es vital para completar servicios de salud, y en Cuba un operador logístico especializado se enfoca en el logro de la disponibilidad de medicamentos acorde a las demandas de los pacientes. El artículo presenta la cadena de suministro de medicamentos y la evolución en su gestión desde el 2015. Para la evaluación cualitativa de su desempeño se emplea como herramienta metodológica el Modelo de Referencia de Redes de Valor. El resultado muestra que en el 2008 la cadena de medicamentos alcanza un desempeño medio, y basándose en ese diagnóstico se trazaron proyectos de desarrollo según las necesidades identificadas. La cadena de valor de medicamentos en Cuba es referencia del apoyo logístico que sustenta este sistema de salud y para otras cadenas en Cuba, al demostrarse niveles de gestión superior a la media nacional de tres puntos.

Palabras clave: cadena de valor; logística; cadena de suministro de medicamentos; Modelo de Referencia de Red de Valor 


\section{Introduction}

Current trends in business competitiveness indicate the need for interconnected links to meet the needs of consumers of increasingly variety of products and services. For commercial and consumer products companies, the main work is focused on keeping the value chain operation updated [1], [2], in order to minimize costs and increase customer service results. However, the application of supply chain management approaches transcends the mass consumption segments and they are applied to spheres of social impact such as health [3]. A sector in which the logistics operators specialized in the activity must have exceptional performance, due to the impact they have on society [3], [4].

For health systems, whatever their structure and functioning, the medicines availability at the consumption points is an attention focus, not only for the hospitals, polyclinic, and pharmacies managers; but also for transporters, storekeepers, manufacturers and raw materials suppliers [5]-[7]. Depending on the patients and the pathology nature, medications must move efficiently through different logistic channels to mitigate diseases and save lives.

In the case of medicine value chains, entities are developed to cover logistics processes in the management of medicines from suppliers to health centers [8]. As there are specialized logistics operators in the world, there are also operators dedicated to the pharmaceutical sector and to manage the value networks of this type of products [4]. The importance of this specialization lies fundamentally in the acquisition of technical knowledge for the handling, transportation, storage, conservation and distribution medicines; in order to maintain quality logistics standards in these important products [5], [9], [10].

Despite the importance of drug logistics operations, there are few research focused on improving the performance of the supply chain management from the patient's point of view. Some of the recent articles focus largely on production and not on health care outcomes, and do not even mathematically model the behavior of a traditional supply chain [11], [12].

In the case of the Cuban health system, this is based on social principles that provide free and quality access to all citizens. It is structured from access to primary health care in the communities (family doctor and polyclinics) combined with services in hospitals and specialized institutes [13]. The tangible results of the Cuban health sector are corroborated by positive statistics and global references, such as: low rates of infant and maternal mortality, and universal health coverage for all citizens [14].

The logistic support of the Cuban health system is given at least for three different enterprises; the medical supplies distributor, non-medical supplies distributor and the medicines distributor. The last one is named Medicine Distribution Company (EMCOMED), and it is called to transform in the specialized logistic operator of the Biotechnological and Pharmaceutical Group (BioCubaFarma) [15]. BioCubaFarma groups the entities that carry out the imports, research, development and production of medicines for the National Public Health System. 
For more than 10 years, EMCOMED has carried out improvement work on its processes, guided by the research results of several universities [16], [17]. It is also an important part of the case studies that have allowed the development of some of the methodologies available in Cuba in the field of logistics and supply chain. One of these tools is the Reference Model of the Value Chain (RMVC) that allows evaluating the supply chain management level and determining the good and bad practices on it [18].

The general objective of this work is to show the evolution on the management level of the Cuban medicines supply chain through the RMVC, and to propose the projects that allow improving the delayed elements on each evaluation.

Although EMCOMED maintains favorable economic results [19], it is necessary to systematically evaluate the performance of logistics and the management of supply chains. EMCOMED, as network coordinator, evaluates the results and identifies the strengths and weaknesses, which contributes to redefining the strategies to increase efficiency and effectiveness in the value chain for the next periods. This evaluation is an important part of the Integrated Supply Chain Management Model that guides the medicine supply chain evolution.

\section{Materials and methods}

The Integrated Supply Chain Management Model (ISCMM) is based on the characteristics defined by the RMVC [20], and this in turn is the measure of the evolution level of the studied supply chain (Figure 1). The systematic evaluation of a supply chain, makes possible to keep update the performance evaluation and allows to define, based on a qualitative analysis of the results, in which development stage it is [21], [22]. These stages are:

- Stage 1: Center in organization and internal integration of the supply chain companies.

- Stage 2: Based on organization of the supply chain integration.

- Stage 3: Focus on consolidation of the bases and techniques for the supply chain integrated management.

- Stage 4: Based on integrated innovation and knowledge to expand the final products and services, and improve their competitiveness. 
Figure 1. Integrated Supply Chain Management Model (ISCMM)

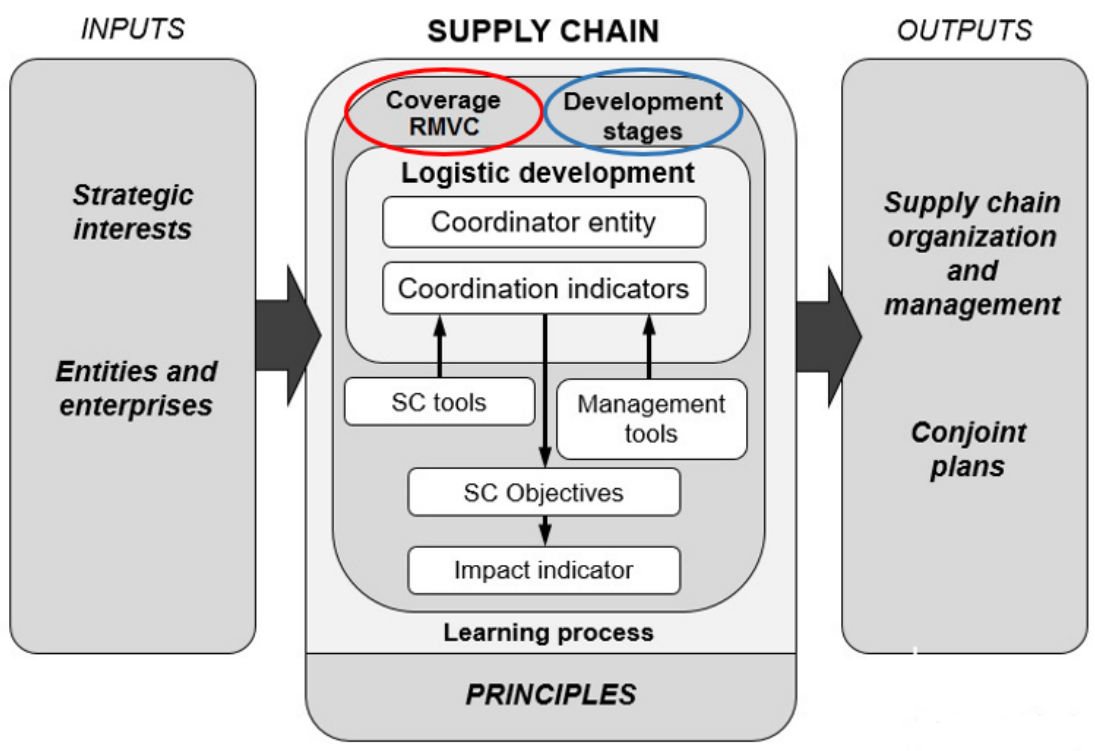

Source: [23].

The RMVC was developed by the Logistic and Production Management Laboratory (LOGESPRO®) from the Technological University of Havana (CUJAE). To create this model, the conjugation of case studies, semantic and mathematical models and experimentation in the selected objects, was used as research methodology [24]. For the generalization of the model, it has been applied in more than 270 companies on Cuba and Bolivia [18], [24], [25] (Figure 2). It contains 144 characteristics grouped into 15 conceptual modules that reflect the best practices on value chain [18].

Figure 2. Reference Model of Value Chain

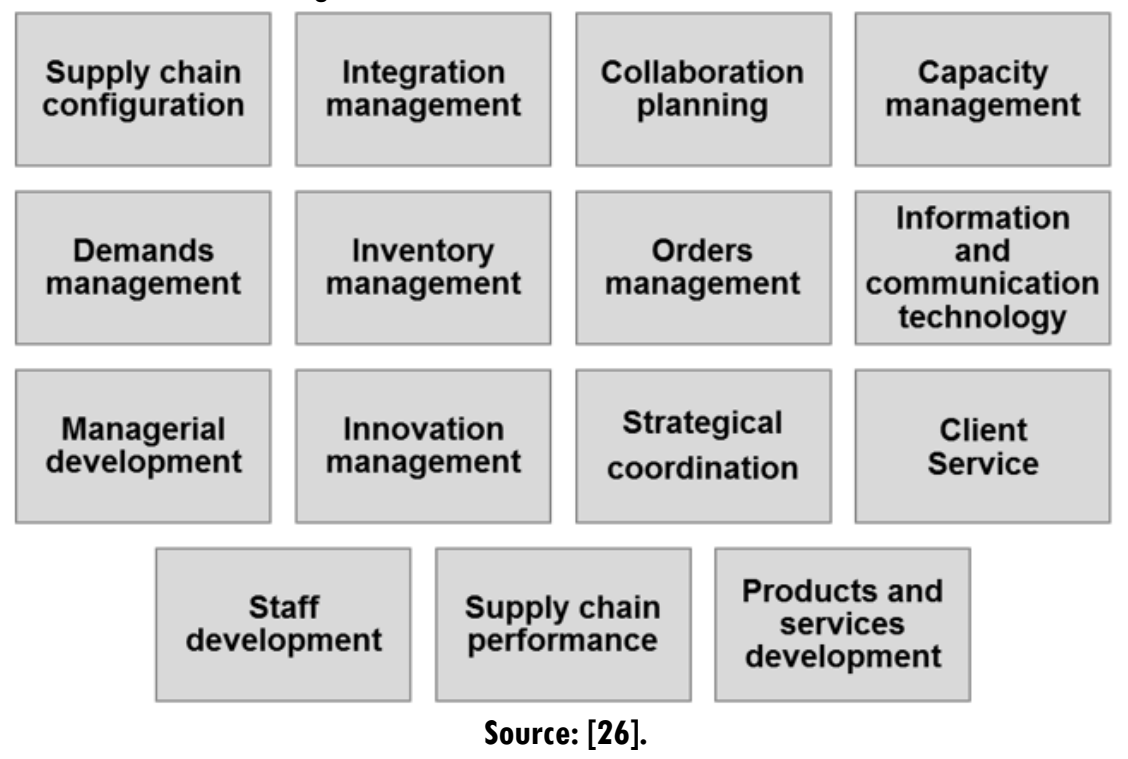


For the characteristics evaluation, a Likert scale of five points is used; where one is "very bad" and five is "excellent." Once evaluated, the average, the standard deviation, the minimum, the maximum and the stability of each one are calculated. If the stability is low or there is a large standard deviation, the characteristic should be reevaluated to find consensus. Every characteristic is classified as "severe weakness" (less than two), "weakness" (between two and three), "acceptable" (between three and four) or "strength" (more than four).

The result of each module are calculated as the average of all it characteristics, and there are classified as "very bad" (below 1.5), "low lever" (between 1.6 and 2.9), "medium level" (between 3 and 3.8), "high level" (between 3.9 and 4.4) and "excellence" (greater than 4.5). The final result is calculated from the average evaluation of the modules given by each of the respondents. This Value Chain Management Level (VCML) is used to determinate in which Stage is the supply chain. The frontiers of each Stage are determinate for 2.5, three, 3.5 and four points, from the first stage to the four.

For a simplest evaluation of the RMVC an Excel application was programed for do all the calculation and result. The users only have to evaluate each characteristic and to analyze the results. All the result (characteristic, modules and VCML) can be compared with historical data from other evaluations in Bolivian, Colombian and Cuban companies [25]. Finally, from the characteristics with "severe weaknesses" and "weaknesses," and from the modules with "very bad" and "low level," the projects are elaborated to improve them and thus increase the VCML.

The application of the Reference Model can be done by three methods; survey a significant sample of workers, according to the criteria of expert consultants or through a guided survey in training workshops. The selected mode depends on the preparation of the personnel, the time available for the evaluation and the number of times that has been done previously. Also, it can be used to evaluate a set of supply chains for comparison or to get general conclusions about an economic sector or a country [2].

\section{Results}

The Reference Model had been applied at the medicine supply chain twice, in 2015 and 2018. Although this chain makes continuous improvements, it is considered that its annual evaluation of the RMVC would not provide significant differences. This is a strategic evaluation model and the implementation of improvement projects derived from it requires more than one year.

Both times, the study was carried out with the participation of EMCOMED Headquarters, the Havana distribution center and the logistics activities areas of San José and Old Havana. Although the company has representation throughout the country, Havana is the most complex area, because in addition to the greater concentration of specialized hospitals and institutes, it is the point from which all imports and exports of medicines are made. 


\section{The medicines supply chain}

The Cuban medicines supply chain is coordinated by EMCOMED, as a specialized logistics operator for the pharmaceutical sector [16]. This company is focused on establishing national and international alliances to manage the medicines demands. The medicines that must be guaranteed can be found in the Basic Medicine Table, a document defined every year by the Public Health Ministry according to the morbidity of the Cuban population [27].

The costumers of this supply chain are the patients that receive treatment al hospitals, policlinics, specialized institutes or bay at the drugstore system in all the country. In addition, there are customers located in different countries (Figure 3), so this part of the medicine supply chain exports and connect with other countries health systems [28]. This network is also responsible for importing raw materials for national laboratories and for medicines that are not produced in the country.

Figure 3. Medicine supply chain for the Cuban health system

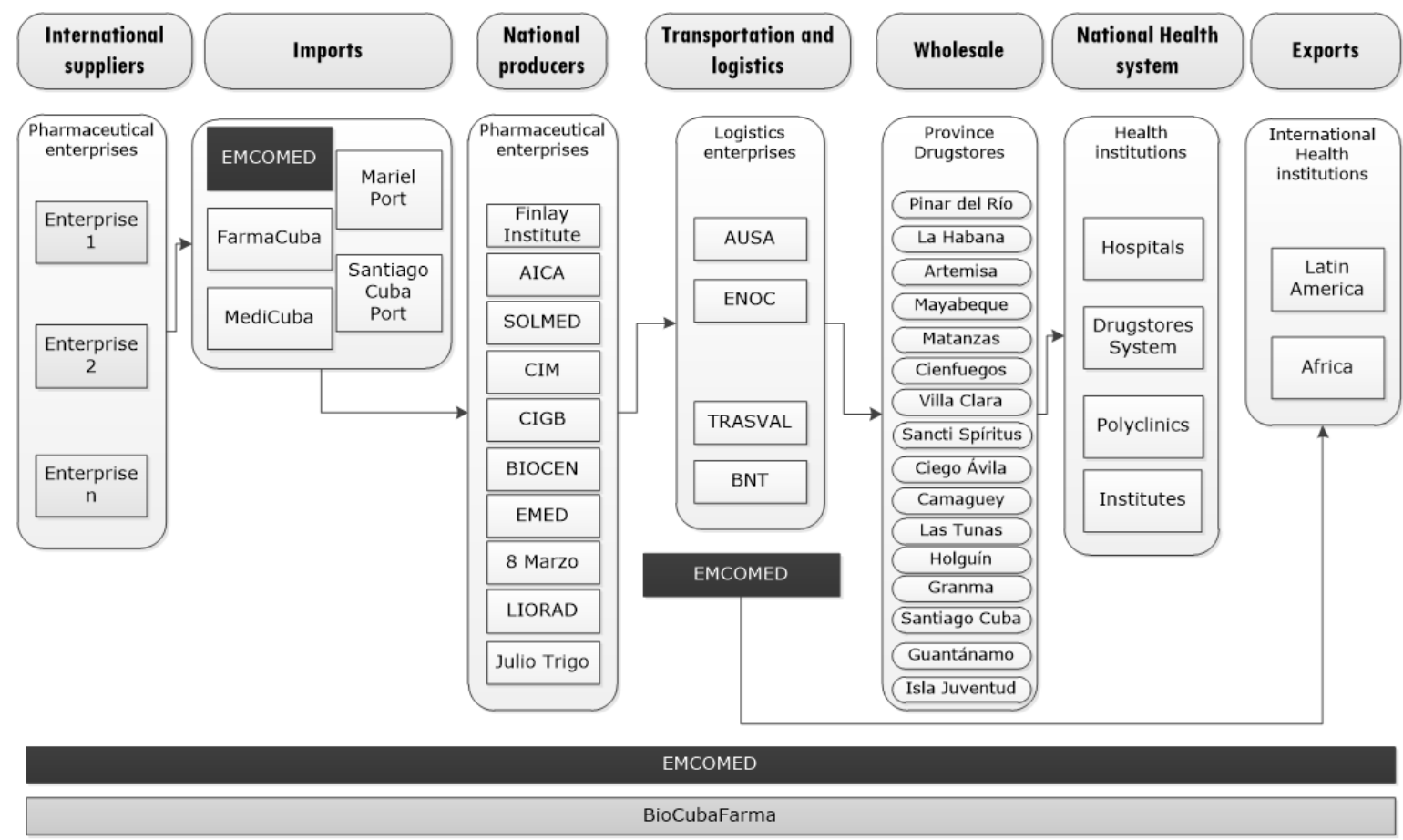

Source: Authors own creation.

The fundamental objective of the medicine supply chain is to increase the levels of patient satisfaction based on the availability of medicines in the consumer network. [29]. The key performance indicator of this supply chain is the availability of medicines in pharmacies and health centers. The objective value is to maintain and exceed $90 \%$ of the availability of all medications. 


\section{First Evaluation of the Reference Model of Value Chain (2015)}

The first application of the reference model was on 2015, at that time was used a guided survey in training workshops due to low staff preparation in logistic terms. The workshops started with 200 people from to the EMCOMED offices in Havana and San José, of which $16.5 \%$ did not complete the evaluation for different reasons. The 167 final respondents belong mainly to the EMCOMED, Havana Drugstore, Old Havana distribution center and San Jose's Logistic Platform; since, at this moment, the rest of the supply chain actors were not very involved.

The results evaluated and discussed among the participants showed a "low level" of supply chain management (2.68) and 50 "severe weaknesses." Among the modules with more "severe weaknesses" are found; Integration Management (6), Order Management (6), Information and Communication Technology (5) and Customer Service (5).

Only Chain Configuration, Demand Management, Supply Chain Performance, and Products and Services Development are evaluated at the "medium level," the rest is classified as "low level." The Collaborative Planning module was the module classified as "severe weakness" since its general evaluation is two points, the lowest among all the modules.

On the other hand, four "strengths" were defined, which are mostly associated with the nature of the pharmaceutical business and the National Health System.

1. The supply chain extends strategically in different territories, which guarantees competitive processes and competitive access to the target markets.

2. The procedures for managing the final consumers' orders are clearly established and documented.

3. Consumers recognize an acceptable price in the final products and services of the supply chain.

4. The final products and services are backed by an updated register of trademarks and patents.

The Value Chain Management Level (VCML) is "low lever" with 2.68 point as average and it is on the second development Stage; "Based on organization of the supply chain integration" (between 2.5 and 3). It means that it is necessary to focus on create procedures and tools that allows to integrate the supply chain.

\section{Defined projections for the medicine value chain for 2015-2018}

1. Comprehensive training plan on logistical issues with LOGESPRO®; start of Logistics Professional Qualification and short training courses.

2. Implementation of the Supply Chain Planning and Control System based on Collaborative Logistic Flow Management Model [30].

3. Definition of the services portfolio in the supply chain; inclusion of new services such as clinical trials. 
4. Definition of the new routing procedure for primary distribution (to distribution centers), using geo-referenced systems and continuous updating.

\section{Second Evaluation of the Reference Model of Value Chain (2018)}

This evaluation was made according to the criteria of expert consultants (the authors) and with the verification of information in several processes of the supply chain. Some pharmaceutical enterprises as CIM, Julio Trigo, 8 de Marzo and AICA; the importers FarmaCuba and MediCuba; and hospitals and drugstores were visited (see Figure 3). This type of evaluation was selected by the author level of knowledge of the supply chain for having carried out several projects for years.

Of the 51 "severe weaknesses" detected in the previous evaluation (2015), at this moment they still persist 23. The rest has gone to "weaknesses" or has been resolved becoming an "acceptable" classification. Regarding the modules qualification, all are "medium level," except for the Strategic Coordination that is still a "low level."

This time, nine characteristics are determined as supply chain "strengths," five more than in 2015:

1. There is a short-term coordination of the guarantee of the capacities in all the processes of the supply chain and this is in the function of the sales plans for the final customers.

2. There are and policies of active participation in social development (life quality, education, culture and health) of workers and the community.

3. As part of the implementation of the strategic plans, a well-defined procedure is applied to redesign the logistics system of the supply chain.

4. The different customer segments are properly identified and differentiated.

5. For each customer segment, a custom design of customer service is available.

The Value Chain Management Level (VCML) is "medium level" with 3.32 point as average and it is on the third development Stage; "Focus on consolidation of the bases and techniques for the supply chain integrated management" (between 3 and 3.5). This stage involves improving and maintaining the coordination of the supply chain, now with the direct participation of companies that are not yet directly involved in the integrated management of the medicine supply chain. The active incorporation of pharmacies, hospitals and the Public Health Ministry is essential.

\section{Defined projections for the medicine value chain for 2018-2022}

Since 2017, EMCOMED is aware of the need to become a 4PL (Fourth Party Logistics) logistics operator, so in this new stage a single project is defined: "Conversion of EMCOMED into the logistics operator 4PL of BioCubaFarma" [15]. This project has several subprojects; which will work once again, with consultants and students from LOGESPRO®. 
1. Determination of variables that influence the demand for medicines.

2. Complete application of the Integrated Supply Chain Management Model.

3. Redesign of logistics system.

4. System of training and certification in logistics skills.

5. Redesign of secondary distribution system (to final clients) in the Havana Drugstore.

6. Definition of the services portfolio for the 4PL logistic operator.

7. Definition of the storage procedure with automatic identification of data in the Havana Drugstore.

8. Definition of the Balanced Scorecard for the medicine supply chain.

9. Financial scheme of the medicines value chain.

10. Traceability system of medicines in the supply chain.

11. Maintenance management of automotive transport fleets.

12. Information systems integrated management in the medicines value chain.

\section{Comparison of the two years results and Cuban enterprises}

As shown in the previous sections, the medicine supply chain has evolved from the projects implemented to eradicate its weaknesses. Figure 4 shows the evaluation by modules and general of the two evaluations carried out in EMCOMED and the results obtained in a representative sample of Cuban supply chains evaluated on 2013 [25]. The sample of Cuban companies is a representative group of companies in "Business Perfection," a model that has guided the management improvements in a group of companies in the country. 
Figure 4. Results of the medicine supply chain in 2015 and 2018, and also Cuban supply chains

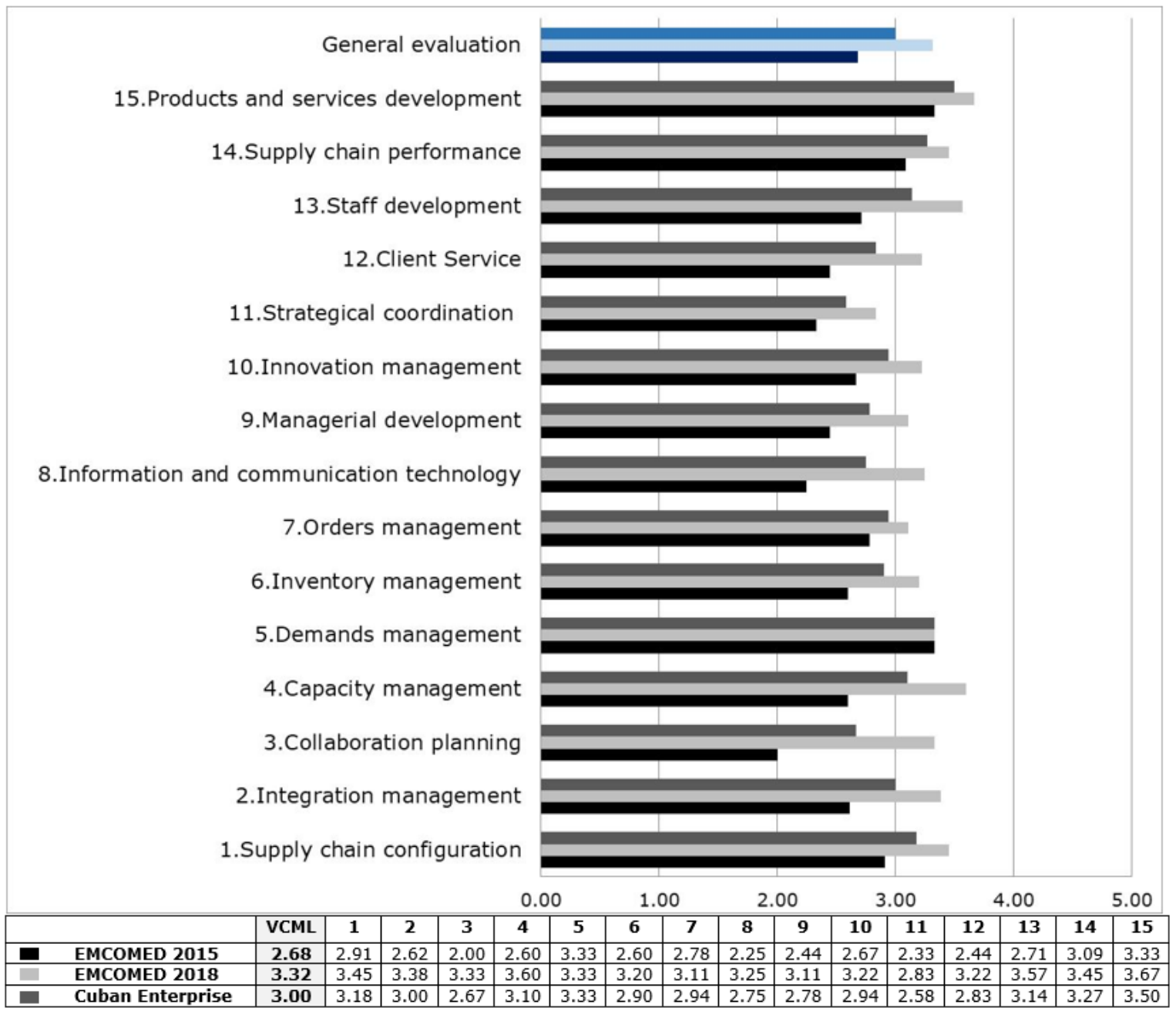

Source: Authors own creation, using [25].

The previous figure shows the substantial improvement in all the modules in EMCOMED between the two evaluations. It is also evident, since the compliance level of RMVC increased from $53.6 \%$ to $66.4 \%$, out of a total of 720 points representing excellence (144 characteristics of 5 points). The medicine supply chains still have $33.6 \%$ of characteristics' improvement to reach excellence on the patients' demands.

When the evaluation of the EMCOMED modules is compared with the Cuban companies, it is evident that the improvements executed between 2015 and 2018 have made the performance of EMCOMED higher than the average of the companies.

\section{Conclusions}

The concepts associated with the management of the value chain have a direct applicability in the supply chains of medicines that make up the health systems of the countries. These are important resources to guarantee the complete treatment and patients' satisfaction, as the 
final client of this network. The Value Chain Reference Model guides the definition of strategic projects and is based on the knowledge generation in the chain from the training and universities and research centers participation.

The evaluation of the Cuban medicine supply chain shows an evolution from 2015 to 2018. The actual management level on this supply chain is 3.32 for a "medium level." The next step should be continues working on integration with all the partners and in the consolidation of the information system for coordinated management in charge of EMCOMED, as logistic operator for the pharmaceutical sector.

This fact, that the VCML in the medicine supply chain is higher than the average of Cuban companies, demonstrates the validity of the Integrated Supply Chain Management Model to achieve progress in terms of integration, efficiency and effectiveness in the supply chain, and the Value Chain Reference Model as measurement and guide of these improvements.

\section{References}

[1] L.E. Carretero and S.R. Pires, Gestión de la cadena de suministros. Madrid: McGrawHill/Interamericana, 2007.

[2] S. Onno Omta and S.J. Hoenen, "Three fundamental perspectives on Supply Chain Management. A literature review," in Las redes de cadenas de valor alimentarias en el siglo XXI: retos y oportunidades internacionales. Madrid: Editorial Agrícola Española, 2012, pp. 41-72.

[3] B. Ageron, S. Benzidia, and M. Bourlakis, "Healthcare logistics and supply chain - issues and future challenges," Supply Chain Forum Int. J., vol. 19, pp. 1-3, 2018.

[4] J. Carreño and J. Garcés, "Diseño del modelo de operación logístico del centro de distribución del Laboratorio Siegfried S.A. para evaluar y recomendar la conveniencia de manejarlo directamente o tercerizado," Proyecto de Grado, Departamento de Logística Ingeniería Industrial, Pontificia Universidad Javeriana, Bogotá, 2015.

[5] C. Sykes, "Time- and Temperature-Controlled Transport: Supply Chain Challenges and Solutions," P T, vol. 43, no. 3, pp. 154-170, 2018.

[6] Cámara Empresaria de Operadores Logísticos (CEDOL), Grado de tercerización de las operaciones logísticas. Buenos Aires: Cámara Empresaria, 2015 [online]. Available: http://www.cedol.org.ar/down/Grado-de-Tercerizacion-de-las-Operaciones-Logisticas.pdf

[7] Cámara Empresaria de Operadores Logísticos (CEDOL), Logísticos, innovación y productividad en las operaciones logísticas, vol. 1. Buenos Aires: Cámara Empresaria, 2017.

[8] V. Bibiana, E. Cortés, and E. Olaya, "Estudio descriptivo de los operadores logísticos como componentes estratégicos dentro de la cadena de valor del medicamento en Bogotá," Rev. Colomb. Cienc. Quím. Farm., vol. 39, pp. 168-187, 2010. 
[9] P. C. Ocampo Vélez and L. Rodríguez, "Estrategias de mejoramiento en la logística de cadena de frio para productos farmacéuticos," CONTEXTO, vol. 5, pp. 105-114, 2016.

[10] J.A. Acevedo, M.I. Gómez, T. López, and A.J. Acevedo, "Retos del sistema logístico de medicamentos en Cuba," paper presented at the IDIFARMA 2018, La Habana, 2018.

[11] M. Imran, C. Kang, and M. Babar Ramzan, "Medicine supply chain model for an integrated healthcare system with uncertain product complaints," J. Manuf. Syst., vol. 46, pp. 13-28, 2018.

[12] E. Settanni, T.S. Harrington, and J.S. Srai, "Pharmaceutical supply chain models: A synthesis from a systems view of operations research,” Oper. Res. Perspect., vol. 4, pp. 74-95, 2017.

[13] Ministerio de Salud Pública de Cuba. Anuario estadístico de Salud 2018. Available: http://files.sld.cu/bvscuba/files/2019/04/Anuario-Electr\%C3\%B3nico-Espa\%C3\%B1ol-2018-ed2019-compressed.pdf

[14] R. Morales Ojeda, P. Mas Bermejo, P. Castell-Florit Serrate, C. Arocha Mariño, N.C. Valdivia Onega, D. Druyet Castillo, et al., "Transformaciones en el sistema de salud en Cuba y estrategias actuales para su consolidación y sostenibilidad.," Rev. Panam. Salud Púb., vol. 42, 2018. https://doi.org/10.26633/RPSP.2018.25

[15] M.I. Gómez, J.A. Acevedo, and A.N. Neira, "Bases de la organización de EMCOMED como operador logístico de la cadena de suministro de medicamentos," paper presented at the IDIFARMA 2018, La Habana, 2018.

[16] I. Lopes Martínez, “Cadena de suministro de medicamentos”, Nueva Empresa, vol. 7, 2011.

[17] R.E. Batista Moreno, Y.O. Lao León, and M.R. Moreno Pino, "Propuesta de ruteo de vehículos en la distribución física de la EMCOMED Holguín," Revista de Investigación Latinoamericana en Competitividad Empresarial, vol. 1, 2019.

[18] J.A. Acevedo Suárez and M.I. Gómez Acosta, "Modelo de referencia de la red de valor en Latinoamérica," in La cadena de valor agroalimentaria. Análisis internacional de casos reales, J. Briz and I.D. Felipe, Eds. Madrid: Editorial Agrícola Española, 2011, pp. 254-294.

[19] A.L. Monzón Ebakn, A. García Fariñas, and M. d. 1. C. Marrero Araújo, "Eficiencia en la distribución de medicamentos en las droguerías cubanas durante el año 2016," Revista Cubana de Salud Pública, vol. 45, 2019.

[20] J.A. Acevedo Suárez, M.I. Gómez Acosta, M.L. Igor, Y. Pardillo Báez, A.J. Acevedo Urquiaga, N. Sablón Cossio, et al., "Modelo de gestión integrada de las cadenas de suministro," Anales de la Academia de Ciencias de Cuba, vol. 5, p. 12, 2015.

[21] M.I. Gómez and J.A. Acevedo, La logística moderna en la empresa, 3a. ed. La Habana: Editorial Universitaria Féliz Varela, 2017.

[22] J. Donald, C. Bowersox, J. David, and M. Cooper, Supply Chain Logistics Management. New York: McGraw-Hill Education, 2012. 
[23] T. López Joy, "Modelo y procedimiento para el desarrollo de la gestión integrada de cadenas de suministro en Cuba,” tesis de Doctor en Ciencias Técnicas, Departamento de Ingeniería Industrial, Instituto Superior Politécnico José Antonio Echeverría, Ciudad de La Habana, 2014.

[24] J.A. Acevedo Suárez, A.J. Acevedo Urquiaga, M.I. Gómez Acosta, T. López Joy, and Y. Pardillo Báez, "Modelo de referencia de redes de valor para un desarrollo sostenible," Rev. Investig. Agraria Ambiental, vol. 1, p. 20, 2010.

[25] M.I. Gómez Acosta, J.A. Acevedo Suárez, Y. Pardillo Báez, T. López Joy, and I. Lopes Martínez, "Caracterización de la logística y las redes de valor en empresas cubanas en perfeccionamiento empresarial," Ing. Ind., vol. 34, no. 2, p. 15, 2013 [online]. Available: http://scielo.sld.cu/scielo.php?script=sci_arttext\&pid=S1815-59362013000200010

[26] J.A. Acevedo Suárez, "Modelos y estrategias de desarrollo de la logística y las redes de valor en el entorno de Cuba y Latinoamérica," tesis para optar por el grado de Doctor en Ciencias, Facultad de Ingeniería Industrial, CUJAE, La Habana, Cuba, 2008.

[27] Dirección de Medicamentos y Tecnologías Médicas, Ministerio de Salud de Cuba, Cuadro básico de medicamentos y productos naturales, 2018 [online]. Avalaible: https://www.cecmed.cu/sites/default/files/adjuntos/vigilancia/farmacov/cuadro_basico_medicame ntos_2018.pdf

[28] C. Peña, "Evaluación de la cadena de suministro de medicamentos en Cuba," Tesis diploma, Departamento Ingeniería Industrial, CUJAE, La Habana, 2018.

[29] N. Sablón Cossio, A.J. Acevedo Urquiaga, M. Pérez Quintana, and J.A. Acevedo Suárez, "Modelo de planificación colaborativa estratégica en cadenas de suministro: casos de estudio," in Nuevas tendencias en Investigación de Operaciones y Ciencias Administrativas: un enfoque desde estudios iberoamericanos. Barranquilla, Colombia: Universidad Simón Bolívar, 2018, pp. 75-114.

[30] A.J. Acevedo Urquiaga, J.A. Acevedo Suárez, and A.J. Urquiaga Rodríguez, "Modelo de gestión colaborativa del flujo logístico," in TECNOGEST, La Habana, 2015. 